\title{
The Impact of Lagging-Region Status on District Poverty in Indonesia
}

\author{
Rus'an Nasrudin ${ }^{\mathrm{a}, *}$ \\ ${ }^{a}$ Arndt Corden Department of Economics, Crawford School of Public Policy, Australian National University
}

\begin{abstract}
Reducing subnational imbalances of development progress is unquestionable policy for heterogeneous Indonesia. This paper examines the impact of policy that assigns a lagging-region status namely status daerah tertinggal (DT) on poverty rate and poverty gap among districts in Indonesia in the two period of SBY presidency. The panel data fixed effect combined with propensity score matching is used to tackle the selection bias due to the nature of the policy, unobserved heterogeneity and omitted variable bias. The results show that the lagging-region status that was aimed to mainstream central and district's budget toward lagging regions statistically significant reduces poverty rate and poverty gap in the period. The DT status, on average is associated with 0.75 percentage point of reduction in the poverty rate and $7 \%$ reduction in the poverty gap index.
\end{abstract}

Keywords: Lagging Regions; Poverty; Indonesia

\begin{abstract}
Abstrak
Menurunkan ketimpangan antar-daerah adalah sebuah agenda kebijakan yang niscaya untuk Indonesia yang majemuk dalam kemajuan ekonomi. Artikel ini berusaha mengukur dampak dari sebuah kebijakan penetapan daerah tertinggal terhadap dua ukuran kemiskinan, yaitu tingkat kemiskinan dan kedalaman kemiskinan pada dua periode masa jabatan Presiden SBY. Metode yang dipergunakan adalah panel data fixed-effect dikombinasikan dengan propensity score matching untuk mengatasi permasalah endogen pada variabel utama yaitu bias dalam seleksi terhadap kebijakan, keragaman daerah yang tidak dapat diukur, dan potensi bias karena ketiadaan variabel-variabel yang berpengaruh terhadap dua ukuran kemiskinan. Hasil pendugaan regresi tersebut menunjukkan bahwa penetapan daerah tertinggal yang ditujukan untuk mengarusutamakan dana pembangunan secara statistik signifikan dan menyebabkan penurunan tingkat kemiskinan dan kedalaman kemiskinan di masa tersebut. Daerah tertinggal secara rata-rata memiliki tingkat kemiskinan lebih rendah sebesar 0.75 (persentase) dan memiliki indeks kedalaman kemiskinan 7\% lebih rendah.
\end{abstract}

Kata kunci: Daerah Tertinggal; Kemiskinan; Indonesia

JEL classifications: I32, P48

\section{Introduction}

Reducing imbalances of subnational development outcome is one of important policy agenda Indonesia in 2004-2009 (Tuwo 2010). The importance mainly because of large differences in socio economic share among regions and islands. Over more

\footnotetext{
The author would like to thank Indonesia Endowment Fund for Education (LPDP) for sponsoring the research through Indonesia Presidential Scholarship.

* Corresponding Address: Arndt Corden Department of Economics, Crawford School of Public Policy, Australian National University. E-mail: rusan .nasrudin@gmail.com.
}

than a decade since the government announced decentralization reform and the aftermath of Asian financial crisis, the dispersions of some economic indicator has been remain unchanged.

In 1997, Java that represents only slightly over $6 \%$ of total land area, accounts for $64.1 \%$ of total non-oil GDP. In 2013, this figure had been slightly lowered to $57.78 \%$. In 1997, the per capita income of the richest province (DKI Jakarta) was almost fourteen times than the poorest (East Nusa Tenggara). This figure even larger in 2011, it had become sixteen times (Akita \& Alisjahbana 2002). 
Despite these unpleasant figures, the poverty measure seems to have better improvement. In 2003, the poverty rate in Papua Province was almost twelve times than of DKI Jakarta Province and the gap has been narrowed to about eight times in 2013 (BPS Statistic Indonesia 2004, 2014). However, as detected by Vidyattama (2013) and Akita et al. (2011) there has been increasing levels of inequality within regions and among districts within provinces in the least equal region.

This promising improvement on poverty status of the districts has brought about concern for policy making to introduce the new policy approach to speed up the convergence poverty figure. One of the new approach is known as lagging region/district status establishment (Penetapan Daerah Tertinggal/DT during President SBY administrative period. This new approach was introduced with slightly different feature with that of the intervention at village level during the Soeharto era (known as IDT-Inpres Desa Tertinggal Akita \& Szeto (2000) as well as at sub-district level during early Reformasi era (known as Kecamatan Development Program (Voss 2008). DT status was designed to improve development outcome at general level i.e administrative level. DT status has two features; is not only development agenda prioritizing policy but also acts as a public fund mainstreaming policy at district level (Ministry of Lagging Region (DT) 2010).

This study aims to evaluate the impact of DT policy in reducing poverty at sub-national (districts and cities) level in Indonesia. We acknowledge that poverty reduction is not the only objective of DT policy where the government also aims to faster economic growth and to increase the human development index (HDI) from the assigned regions (Ministry of Lagging Region (DT) 2010). However, this paper focuses on the role of lagging region status in channeling resources to reduce poverty in the targeted regions. The hypothesis in this study is that the assignment of a region as the lagging region (DT status) will attract public fund from both central and subnational budget and further will reduce the poverty status of the district than without the establishment of DT status.

This study finds that the DT status is associated with negative and statistically significant in poverty rate change. DT status caused 0.75 percentage point of poverty reduction. The policy is also as- sociated with 0.34 point reduction in poverty gap. These magnitudes are slightly higher than the estimate without controlling for regional specific effect and district observable specific characteristics. The rest of the paper is organized as follows. I briefly overview some studies of Indonesia's anti-poverty policy in Section 2, explain program design and mechanism in Section 3, describe data and explain model in Section 4, discuss the results in Section 4 and conclude in Section 5.

\section{Literature Review}

The evolution of policy intervention to reduce regional disparities in Indonesia since 1960s has been went through three phases, including the use of Inpres Desa Tertinggal or IDT during Soeharto Era, community and participation basedpolicy driven by donor programs known as Jaring Pengaman Sosial or JPS including PNPM in the few years after reformasi and then programs derived from ministerial and local government budget since the implementation of decentralization in 2001. Each of the phases exhibits mixture impact of the intervention as has been documented by some studies as follows.

Akita \& Szeto (2000) relied on the availability of household level expenditures data, estimated and found that IDT statistically significance improves social equity at province levels. The finding confirms the positive impact of the nature of the program that provides non-repaid working capital in order to increase poor household income on within province inequality. This study also suggests for a wider autonomy to the locals to gain greater impact in combating poverty. As for the PNPMs, Suryahadi et al. (2010) overviewed that the program resulted mixed result in terms of program implementation's monitoring progress. Yet, there has been no quantitative impact measurement of the programs either for the three clusters of the PNPMs. Given the fact that the 1998 crisis caused uneven decline impact on regional GDP, Akita \& Alisjahbana (2002) argues that the regional inequalities are declined as the results of major drop in per capita income in rich provinces including greater Jakarta and Riau. Considering this finding, perhaps, the PNPMs targeting area that are biased to Jawa will less likely improves regional inequality strongly in the couple years following the 
1998 crisis. Lastly, the phase of the social equality promoting program has been developed under the decentralization period that forces the government to use new central-regional government interrelation setting. In which, the President Susilo Bambang Yudhoyono or SBY introduced the enactment of lagging region status or status daerah tertinggal or simply DT status at district level to make it in line with decentralization focus of administrative level. At best of our knowledge, there has been no study to measure the impact of the policy and revealed the causal impact of the status and particular development outcome, in particular poverty.

The selection into the DT status is a result of a mixed approach that constitute both formula and discretion based. The formula is based on 6 criteria, namely economy, human development, local public finance, infrastructure, accessibility and particular regional characteristics by the central government (Ministry of Lagging Region (DT) 2010). The regional characteristics include border region, prone disaster region and region with specific needs (conflict-prone districts) and newly established district or city. The status were given under medium term framework that is 5 years period. The central government then performs evaluation based on the same six criteria to determine whether the region can be stipulated as alleviated region. During 20042009 period there had been 199 regions that were stipulated as DT districts. Among these region, 50 district was granted as alleviated regions in 2009. Along with 34 newly established districts, the remaining regions have been kept as DT district in the period of 2010-2014. This number formed total of 183 DT district within the second period of SBY presidency.

Inferred form thre ministerial decree of the DT status, the way of the policy affect the each indicator was not clearly stated as the policy aims to target broad development indicator. Yet, one can interpret that DT status acts as a mainstreaming of central line ministries program and intergovernmental fiscal transfer toward these DT districts to foster its economic development. This approach was taken as a result of the existing overlapping policy ${ }^{1}$ for

${ }^{1}$ Detecting the existing poverty alleviation program at district local gives us example of community based program such as PNPM (Program Nasional Pembangunan Masyarakat-National Program of People Development as the continuation of Kecamatan Development Program/KDP. underdeveloped regions along with the growing responsibilities of local-district government after the decentralization reform.

It is noticed that the selection into DT status was bias to the underperformed regions in terms of the 6 criteria, including poverty indicator within economy criteria. The selection is also applied into heterogeneous regions in their respective specific characteristics in the seven main island groups (Sumatera, Jawa, Kalimantan, Sulawesi, Maluku, East Nusa Tenggara and Papua). Consequently, an impact evaluation including this study is performed on observational data or non-experimental setting in which selection bias, unobserved heterogeneity and omitted variable bias exist. The omitted variable normally occur when other national intervention on poverty reductions are spotty recorded. Therefore, a two-way fixed effect-panel data analysis combined with propensity score matching technique is used to mimic a counterfactual for the treated (DT) regions to tackle the sources of bias. The available data on DT eligibility criteria at baseline that is two years' time prior to DT stipulation in 2004 is used as the determinants of DT enrollment. In addition, to isolate the effect of time invariant regional (island) effect and time specific trend, this study also include year-island interaction term in the estimation as in Kis-Katos \& Sparrow (2013).

\section{Method}

\section{The Program: Selection and Mechanism}

Law no. 17 year 2007 on the mid-term development plan stated that the concern of the central government toward the development progress of underdeveloped and isolated regions should be more be emphasized at district levels so that these areas can develop more quickly and gain convergence with the other regions. The SBY administration translated this mandate by aligning both central budget for district level (line ministries programs) and local budget to be more specific on regions that are considered lack behind or underdeveloped by granting these region a status, underdeveloped or not. The introduction of lagging region status or DT district 
then is aimed to channel all potential public fund with toward higher priority to these DT districts.

\subsection{Selection Formula}

The eligibility criteria of a district for DT status comprises of 33 indicators that are grouped into six dimensions. They covers economic (poverty rate and per capita expenditure), human capital (life expectancy, years of schooling, and literacy rate), infrastructure (road quality, telephone connectivity, water, traditional market, health facilities, and primary and secondary level schools supply), fiscal capacity, accessibility (average distance of villages to district's capital city, average distance of villages to health and education facilities), and special characteristics (disaster, conflict and conservation). The algorithm to score a region $i$ of criteria $j$ into the group is

$$
\text { score }_{i}=\sum_{j=1}^{33} a_{j} \cdot b_{j} \cdot z_{i j}
$$

where:

$a_{i j}$ : direction of indicator $j(+1$ or -1$)$,

$b_{i j}$ : weight of each $j$,

$z_{i j}$ : standardized value of indicator $j$ across region $i$,

$x_{i j}$ : indicator $j$ of region $i$.

The regions are divided into five even group based on the score. Then, the cut off value of score $e_{i}$ for a region to be included in DT regions is the upper bound of the fourth group of the score. Overall, the selection into DT regions comprises four steps: (i) determining indicator $j$ to be used (ii) calculation of $z_{i j}$ of each indicator $j$ (iii) assigning $(+1$ or -1$)$ for each $j$ and its weight ( $b_{i j}$ (iv) calculating score $_{i}$ and classifying a region into five groups of $m$ with the interval of:

$$
\text { interval }_{m}=\frac{\text { score }_{i-\max }-\text { score }_{i-\min }}{5} .
$$

During the period of 2004-2009, the formula yielded 199 districts as the DT districts in the first phase. Out of this number, $123(62 \%)$ of the regions are located in eastern part of Indonesia, $58(29 \%)$ were from Sumatera and the remaining 18 regions (9\%) were from Java. Among provinces, Papua had the largest members (18 districts) and DKI Jakarta was the only province without DT district.
Claiming for the success of alleviating these 199 regions from their underdevelopment by various affirmative policies, the central government announced that 50 out of 199 regions were categorized as non-DT district in 2009, and it added 34 newly established regions (pemekaran) into the group. This makes the total of stipulated DT regions become 183 in the second phase. Those alleviated regions comprised of 19 regions from Sumatera, 9 from Java, 6 from Borneo, 11 from Sulawesi and the remaining 3 were from Maluku and Papua. The following table shows the trend of DT regions over the two phases within SBY Presidencies.

Table 1: Distribution and Change of Numbers of DT-Region by Island, 2004-2014

\begin{tabular}{lrr}
\hline Island & 2004-2009 & 2010-2014 \\
\hline Sumatera & 58 & 46 \\
Jawa and Bali & 18 & 9 \\
Kalimantan & 21 & 16 \\
Sulawesi & 41 & 34 \\
Nusa Tenggara & 22 & 28 \\
Maluku & 13 & 15 \\
Papua & 26 & 35 \\
\hline Total & 199 & 183 \\
\hline
\end{tabular}

\subsection{Mechanism}

What is the implication for a region being stipulated as the lagging-region? Following the stipulation, the central government sets a mid-term development goal for the regions and documents the in the official policy document called Strategi Nasional Pembangunan Daerah Tertinggal or national strategy of lagging-regions development or known as Stranas$P D T$. Mainly, the strategy aims to accelerate the economic growth of the regions in order to narrow the per capita welfare to those of non-lagging regions. The strategy also emphasizes on the community empowerment and local culture conservation. In the document, including Peraturan Pemerintah Number 7 Year 2014, it is mentioned that it is the role of the Ministry (formerly known as Kementerian Pembangunan Daerah Tertinggal), line ministries, governor and bupati/head of district to translate the plan into actions with the support of fund from central budget (APBN), local budget (APBD) and various additional legal sources, including private fund.

Thus, the mechanism is can be said as a 'main- 
streaming' public and private funds toward the lagging-regions. The administration of the programs comprises of two levels, central and local governments. An example of mainstreaming intergovernmental transfer by this status was the introduction of Special Allocation Fund (SAF) for lagging regions in 2011. The fund was allocated for physical infrastructure improvement. This approach will take effect on poverty through indirect effect as compared to the previous anti-poverty program that are targeted at household and individual levels. In addition to this resource, the line ministries program that are directly managed and allocated by central government at district level have been also became another source of development program for DT districts. These line ministries include Ministry of Public Work, Ministry of Health, Ministry of Education, Ministry of Marine, Ministry of Social Affair and Ministry of Home Affair (Ministry of Lagging Region (DT) 2010).

In addition, the National Planning Agency, conducted field survey to overview the implementation of the roles and one of the finding was, the highest proportion (above $90 \%$ ) of the fund of the project conducted under the stranas-PDT was for physical infrastructure project especially for connectivity such as road, bridge and small ports, small portions goes to community empowerment and direct transfer at household level (BAPPENAS 2009). This mechanism allows us to build a hypothesis of the policy impact's channel toward poverty. Specifically, the program's impact seems through enhancing economic activity in the area that are area of pockets of low-income earners that turns out it improves poverty status of the district.

\subsection{Data and Estimate}

\subsubsection{Data}

This study uses two datasets at district level. The first set of data is the list of DT districts obtained from Ministry of DT both during the first and second term of President SBY presidency. This data then is merged with the social economic data at district level that is compiled at the INDO DAPOER (Indonesia Database for Policy and Economic Research) ${ }^{2}$.

\footnotetext{
2The dataset is available at http://databank. worldbank. org/data/reports. aspx? source=
}

There are three main sub-dataset extracted from INDO DAPOER for this study. The first dataset is the GDP and its decomposition from Statistic Indonesia. The second dataset is sub-national account and budget originated from Ministry of Finance and the last dataset is district characteristics from PODES (The Village Potential Statistic) survey. This study extracts infrastructure data as the DT districts determinants from this survey. The net observations comprises of 441 subnational districts and cities in Indonesia.

At the baseline year (2003), it is shown in Table 1 that the DT districts were inferior in all variables. Both the poverty rate and poverty gap are almost half for DT district compared to the non-DT district. In fact, for the entire period, on average both poverty status has been remaining higher for DT district than non-DT district (Figure 1, Table 5). Among sectoral GDP, it is only GDP on agriculture sector that shows narrow gap between the two group. The other three sectors (manufacture, financial service and service sectors) have significant difference. The fiscal capacity is also slightly lower in DT districts than non-DT districts. Accordingly, to control this selection bias, this study uses difference-in-difference approach that is can be specified as two-way fixedeffect linear regression (Galiani et al. 2005).

The observation in each variable are missing for some district in which yield only 441 out of 523 total districts in the dataset. The attrition in the data is also resulted from dropping newly formed region (pemekaran) that are not exist yet in some years in the sampling period prior to the formation of the respected region. I decide not to use the district of origin to replace the old data on the reasoning that numbers of the newly formed region have different characteristic with their origin districts, especially in terms of fiscal capacity.

The time trends of the poverty status within the policy implementation period and two years prior to the intervention are depicted in Figure 1. Year 2004 was the year of commencement of the policy. It shows that the poverty rate and poverty gap on average has been reduced moderately between 2004 and 2013, owing to many policy contributing factors such as the continuation effect of previous anti-poverty programs (PNMPM, IDT during Soe-

indo dapoer-(indonesia-database-for-policy-andeconomic-research) 
Table 2: Summary Statistic at Baseline (year=2003)

\begin{tabular}{lccc}
\hline & $\begin{array}{c}\text { mean } \\
\text { Variables }\end{array}$ & $\begin{array}{c}\text { mean } \\
(\mathrm{sd})\end{array}$ & $\begin{array}{c}\text { mean } \\
(\mathrm{sd})\end{array}$ \\
\hline DT=1 & DT=0 \\
Poverty Rate (in \% of population) & 17.75 & 24.02 & 14.09 \\
Poverty Gap (index) & $(9.085)$ & $(9.450)$ & $(6.523)$ \\
& 3.352 & 4.870 & 2.467 \\
GDP growth & $(2.392)$ & $(2.922)$ & $(1.408)$ \\
GDP-Service Sector (IDR Trillion, current) & 0.0507 & 0.0493 & 0.0516 \\
& $(0.0935)$ & $(0.130)$ & $(0.0631)$ \\
GDP-Financial Sector (IDR Trillion, current) & 0.346 & 0.181 & 0.442 \\
& $(0.446)$ & $(0.136)$ & $(0.529)$ \\
GDP-agriculture Sector (IDR Trillion, current) & 0.167 & 0.0548 & 0.233 \\
& $(0.379)$ & $(0.0531)$ & $(0.464)$ \\
GDP-Manufacture Sector (IDR Trillion, current) & 0.636 & 0.543 & 0.690 \\
Total Population (in Million of people) & $(0.623)$ & $(0.387)$ & $(0.722)$ \\
& $(2.995$ & 0.114 & 1.350 \\
Total Area (in thousand Km2) & 0.571 & $(0.183)$ & $(3.656)$ \\
Fiscal capacity (IDR Trillion) & $(0.577)$ & $(0.315)$ & $(0.666)$ \\
Special Allocation Fund (IDR Billion) & 4.826 & 8.204 & 2.856 \\
& $(7.779)$ & $(10.51)$ & $(4.615)$ \\
Observations & 0.135 & 0.116 & 0.146 \\
Number of Districts & $(0.125)$ & $(0.0719)$ & $(0.146)$ \\
& 9.233 & 12.15 & 7.532 \\
& $(9.225)$ & $(11.84)$ & $(6.762)$ \\
\hline
\end{tabular}

harto Era), including this DT policy. It was noticeable that the gap between the two groups (DT and non-DT) has been also narrowed for both poverty indicators. We also observed a peak in poverty gap increase due to food price surge in 2008. This paper hypothesizes that partly DT status stipulation contributes to this narrowing gap between the two groups together with the confounding factors within the period of 2004-2013.

\subsection{Estimation Strategy}

\subsubsection{Potential Source of Bias}

The main objective of this study is to measure the average effect of stipulating a district status as underdeveloped region (DT) on poverty status (poverty rate and poverty gap). Fundamentally we want to compare the poverty status when the region is stipulated as DT district with the counter-factual that is the poverty rate when the district have not been granted DT status. However, the comparison is impossible as we only observe once status for each region. Under a non-experimental setting, this study tried to mimic counter-factual by using the non DT districts and solve for potential bias caused by such approach.

Given the nature of non-randomness in the selection process into DT districts, there will be likely that the treatment and control group are different in both observables and the unobservable that correlate with poverty status. For the observables, the DT status is generally designed to alleviate the underdeveloped regions and make them move along convergence path with other developed region. Which means that we have the treatment group that consists most of the underdeveloped regions and the control group that consists most of the developed regions. Therefore, any impact estimate from regressing dummy variable of DT on outcome, will not only capture the program's effect, but also will capture the different group characteristics. There is likely to capture, for example, the effect of each group existing resources (fiscal capacity, existing infrastructure, human capital) to reduce poverty. The developed regions tend to have more abundant resources to reduce poverty than the underdeveloped regions.

The second problem with the selection bias is self-

Economics and Finance in Indonesia Vol. 62 No. 1, April 2016, pp. 30-43 

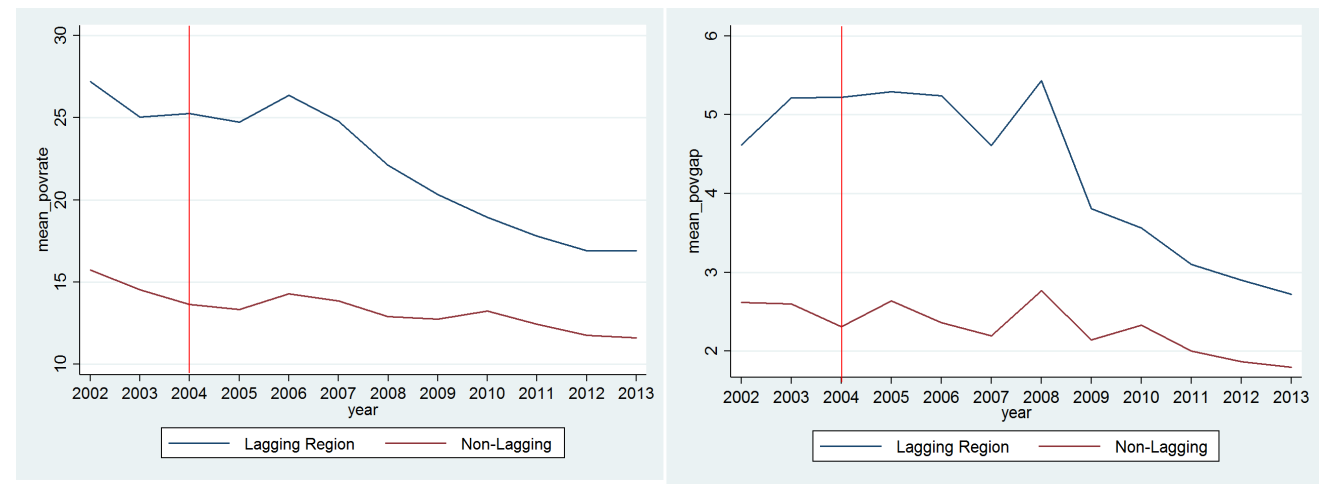

Figure 1: Time Trend of Poverty Status

Source: INDO DAPOER, calculated by Author

selection bias. Arguing for a possibility of unobservable effect, political lobbies, the region which is actually lag behind is likely to put more effort to influence the central government to get the privilege. Despite the central government claims that the stipulation of the DT status is based on an objective formula, given the current institutional setting, the assumption of a self-selection bias is likely hold. In this case, the estimate will not only capture the program effect but also the region's specific effect related to motivation of local government to participate into the program.

A strong indication of these two potential bias is given by the baseline data. On average, the initial level of poverty rate in the DT district will be higher than the control group. There is initial difference for poverty status between the two groups. Table 1 shows that, at the baseline (in 2003) the average poverty rate in the treatment group $(24.02 \%)$ is nearly twice as of the control group (14.09\%). The poverty gap index has similar pattern, it was also twice as the control group (4.9 in treatment and 2.5 in control). This figures indicate that there were initial differences in the outcome variable for the two groups.

\subsubsection{Estimation Strategy: Panel Data-Fixed Effect Combined with Propensity Score Matching (PSM)}

Dealing with the first source of bias, we use twoway fixed effect estimation technique that has similar feature as of difference-in-difference technique to eliminate the initial difference of the dependent variable, assuming that anything else other than observable factors that we include in the equation are moving similar (parallel trends) for both group (Galiani et al. 2005). This assumption will be valid if the parallel trend assumption is hold. It is hard to test this assumption, but we can rely the prior trend program period to check whether the two groups had the same trends. Figure 1 indicates that this assumption is supported by the poverty rate figure and not too much of the poverty gap figure. Accordingly, the estimation will include interaction term of year and island dummy variable to capture this confounding effect resulted from different aggregate shock across the two groups.

The second problem will be challenging as local motivation is unobservable. If we allow to assume that this unobservable is constant over time, the use of fixed-effect panel data estimation will eliminate the time invariant unobservable. The estimation is possible as there is variation in the value of dummy variable of DT status if we includes the period of before the implementation of DT policy, the first phase of DT policy and the second phase.

Another concern about the estimate is that the effect of giving DT status is the potential heterogeneous impact across district on poverty status. For example, disaster prone region will have higher difficulty to reduce poverty than non-disaster prone region. The same argument apply for conflict-prone region and other specific characteristics. Realizing this potential heterogeneous impact, this study follows the approach used by Galiani et al. (2005) and Lewis (2014) to control for the heterogeneity using the observable determinants of the enrollment to the policy or matching approach. Thus, PSM technique

Economics and Finance in Indonesia Vol. 62 No. 1, April 2016, pp. 30-43 
is used to estimate the likelihood of a region to be enrolled in the DT status using set of determinants used by Indonesian government to grant DT status. The resulted common support then is used in a fixed-effect linear regression to control for the heterogeneous impact.

The main estimation is based on the two-way fixedeffect specification as in Galiani et al. (2005) in which being added with the year-island interaction term dummy:

$$
y_{i t}=\beta T_{i t}+\mathbf{X}_{\mathbf{i t}} \gamma+\lambda_{i}+t_{i}+\delta t_{i t} * I_{i t}+\mu_{i t}
$$

Denoting $i$ and $t$ are the district and year indices respectively, $y$ is the poverty status, $T$ is the dummy variable of treatment (equal 1 for DT district and 0 for non DT district in each phase of the periods of policy implementation and 0 for all regions at the base line period), $X$ is the set of covariates that determine the poverty status at district level (growth, sectoral GDP, total population, area, fiscal capacity and special allocation fund (SAF)), $t$ is time specific effect, $\lambda$ is the region fixed-effect, $t * I$ is year-dummy island interaction term to capture time and regional specific effect and $\mu$ is the error term or the time varying unobservable that assumed to be i.i.d to $X$ and $y$.

The PSM specification used to match the DT district with those of non-DT district is based on the following specification that is executed using default logit specification:

$$
P\left(x_{i}\right)=\operatorname{Prob}\left(D_{i}=1 \mid x_{i}\right)
$$

where $\mathrm{x}$ is the set of eligibility criteria for a district to be stipulated as DT district. The estimation is carried into two set periods: baseline of year 2003 and baseline of year 2009 for each of phases of DT policy respectively. Among 18 indicators that formally used by Ministry of PDT, this study is able to collect only 15 indicators. Three set of indicators related to infrastructure namely road quality, health and education facilities are missing because of unavailability of the data at the INDO DAPOER. The author had not been unable to retrieve the data from the original source up to this paper is written. Thus it is acknowledgeable that the alternative estimation using a complete set of 18 indicator might produce slightly different result.

To see the robustness of the common support find tunning, the estimation step is also include four alternatives matching procedure in the PSM equation.
The check found that the commons support is not sensitive to any of four matching procedures, and the main estimation presented is based on Kernel matching with 0.06 bandwidth. The fixed effect estimation on the panel data were also tested against random-effect specification despite the underlying assumption that $E\left(\mu_{i t}, X_{i t}\right) \neq 0$. The Hausman test rejects the null that the two estimates obatined from random and fixed effect are indentical. This result reinforce the use of fixed-effect estimation.

\subsubsection{Split Regions (Pemekaran)}

Implementing panel data strategy at district level in Indonesia will encounter unbalanced nature as the result of split regions or pemekaran. The circumstance gives us two forced options. First is to use FE for never-split only with the consequence of having bias if the RHS variable of interest correlates with split or not-split category. Second is to use RE with kabupaten as cluster, allowing uneven period for each kabupaten. This study chooses the FE strategy because of the potential bias originated from unobserved heterogeneity that only can be purged out using FE or differencing. In 2003, there were 349 kabupaten and 91 kota that make total 440 districts in Indonesia. Out of this number, 199 or $57 \%$ of kabupaten are stipulated as lagging regions by the government for the period of 2004-2009, it was the first term of SBY presidency. During this period, out of these 199 kabupaten, there were 160 kabupaten that had never experienced split or pemekaran or never-split type kabupaten. I stick to these 160 districts in the estimates.

\section{Result and Analysis}

Given the initial difference between the two groups, the OLS estimate picks up the average differences between the two groups. The average difference in poverty rate between treatment and control group is shown by naïve estimation in the first column of Table 2 and the average difference in poverty gap is shown in the first column of Table 3 . It was about $8.6 \%$ and 2 point index respectively for the years of 2004-2013.

Impact estimate based on the preferred specification (i.e the two-way fixed-effect model with year- 
dummy island interaction on common support only) shows that on average, the lagging region status is associated with 0.75 percentage point reduction in poverty rate. This magnitude is equal to $3 \%$ reduction from the baseline rate (the poverty rate at the baseline was $25 \%$ in 2003). The policy is also associated with 0.34 point reduction in poverty gap index. This magnitude is equal to $7 \%$ of the index change (the index of poverty gap at the baseline was 4.9 in 2003).

The impact heterogeneity of the estimate is considered come from the different characteristics of the two groups. To control such heterogeneity, I employ the PSM to control for the observable characteristics among the two group. Here I use the set of criteria used by the official formula to determine the program enrollment. We notice from Table 3 that the impact is slightly higher once we control this characteristics.

The full set of alternative specifications are presented in Table 2 for poverty rate and in Table 3 for poverty gap. Different control variables are used to check the robustness of the estimates. Secondly, the estimates are also tested against different matching method. Table 5 and Table 6 show that the estimates are insensitive from each matching method as all of the four (Kernel, Neighbourhood, Calliper and Radius exactly yield the same common support). They drop 29 out of 87 treatment regions and use all of 169 control group as the common support for the first phase of DT policy (2004-2009). For the second period there were 19 out of 116 treatment that are outside common support and use all 222 control group members.

\section{Conclusion}

This paper aims to measure the average impact of a policy set out during SBY presidency to reduce inequality in development progress among districts in Indonesia. The policy was stipulating district as lagging regions that aimed to mainstream the public fund at national level toward these regions on poverty status, namely DT status. Given the non-randomness of the selection process of the this paper used panel data fixed effect approach to overcome the selection bias due to initial differences (taking the benefit of difference-in difference feature of fixed effect regression) and unobserved heterogeneity as well as potential omitted variables.

The estimates also control for the heterogeneity impact by using observation that are in the common support obtained from PSM estimation. After controlling for the heterogeneity impact, this study found that the impact estimate of DT status is about $2 \%$ for the poverty rate reduction and $7 \%$ for the poverty gap reduction. The results suggest that mainstreaming resource allocation in the presence of overlapping policies in the more decentralized economy will make the underdeveloped regions gain better poverty reduction compare to situation without the policy. This study has a shortcoming for future improvement. The main improvement would be retrieving the three left over determinants of PSM estimation that might reveal a comparable result.

\section{References}

[1] Akita, T, \& Alisjahbana, A 2002, 'Regional Income Inequality in Indonesia and the Initial Impact of the Economic Crisis', Bulletin of Indonesian Economic Studies, vol. 38, no. 2, pp. 201-222.

[2] Akita, T, \& Szeto, JJK 2000, 'Inpres Desa Tertinggal (IDT) Program and Indonesian Regional Inequality', Asian Economic Journal, vol. 14, no. 2, pp. 167-186.

[3] Akita, T, Kurniawan, PA, \& Miyata, S 2011, 'Structural Changes and Regional Income Inequality in Indonesia: A Bidimensional Decomposition Analysis', Asian Economic Journal, vol. 25, no. 1, pp. 55-77.

[4] BAPPENAS 2009, 'Kajian Keserasian dan Keterpaduan Pengelolaan Pembangunan Daerah Tertinggal serta Uji Coba Indikator Kinerja Pembangunan Daerah Tertinggal', Laporan Final, Direktorat Kawasan Khusus dan Daerah Tertinggal Kementerian Negara Perencanaan Pembangungunan Nasional/Bappenas.

[5] BPS-Statistic Indonesia 2004, Statistik indonesia 2003, Badan Pusat Statisitik, Jakarta.

[6] BPS-Statistic Indonesia 2014, Statistik indonesia 2013, Badan Pusat Statisitik, Jakarta.

[7] Galiani, S, Gertler, P, \& Schargrodsky, E 2005, 'Water for Life: The Impact of the Privatization of Water Services on Child Mortality', Journal of Political Economy, vol. 113, no. 1, pp. :83-120.

[8] Kis-Katos, K, \& Sparrow, R 2013, 'Poverty, Labour Markets and Trade Liberalization in Indonesia', IZA Discussion Paper, 7645, Institute for the Study of Labor (IZA), Germany.

[9] Lewis, BD 2014, 'Indonesian Intergovernmental Performance Grants: An Empirical Assessment of Impact', Bulletin of Indonesian Economic Studies, vol. 50, no. 3, pp. 415-433.

[10] Ministry of Lagging Region (DT) 2010, Ministerial Decree No. 04/PER/M/PDT/II/2007-Strategi Percepatan Pembangunan Daerah Tertinggal.

[11] Suryahadi, A, Yumna, A, Raya, UR, \& Marbun, D 2010, 


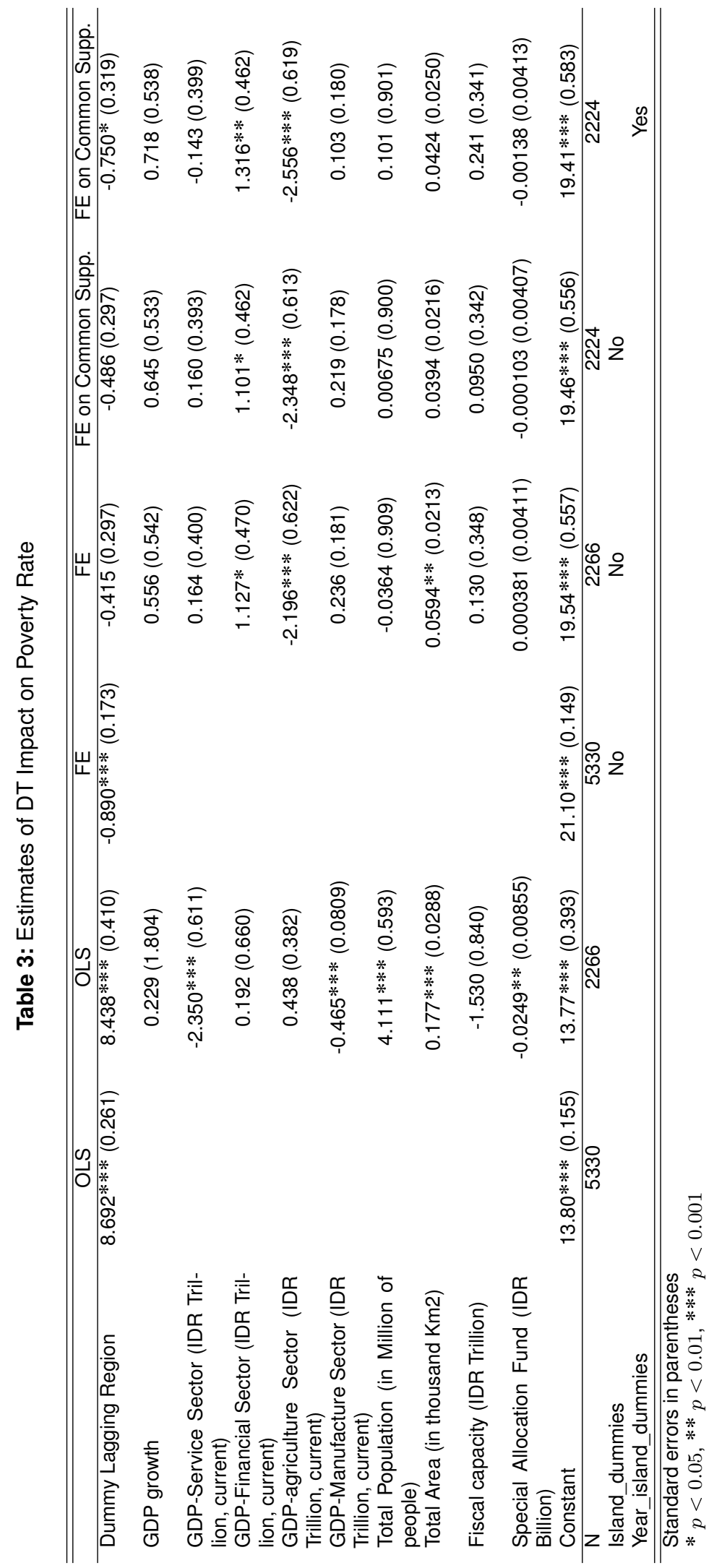

Economics and Finance in Indonesia Vol. 62 No. 1, April 2016, pp. 30-43 


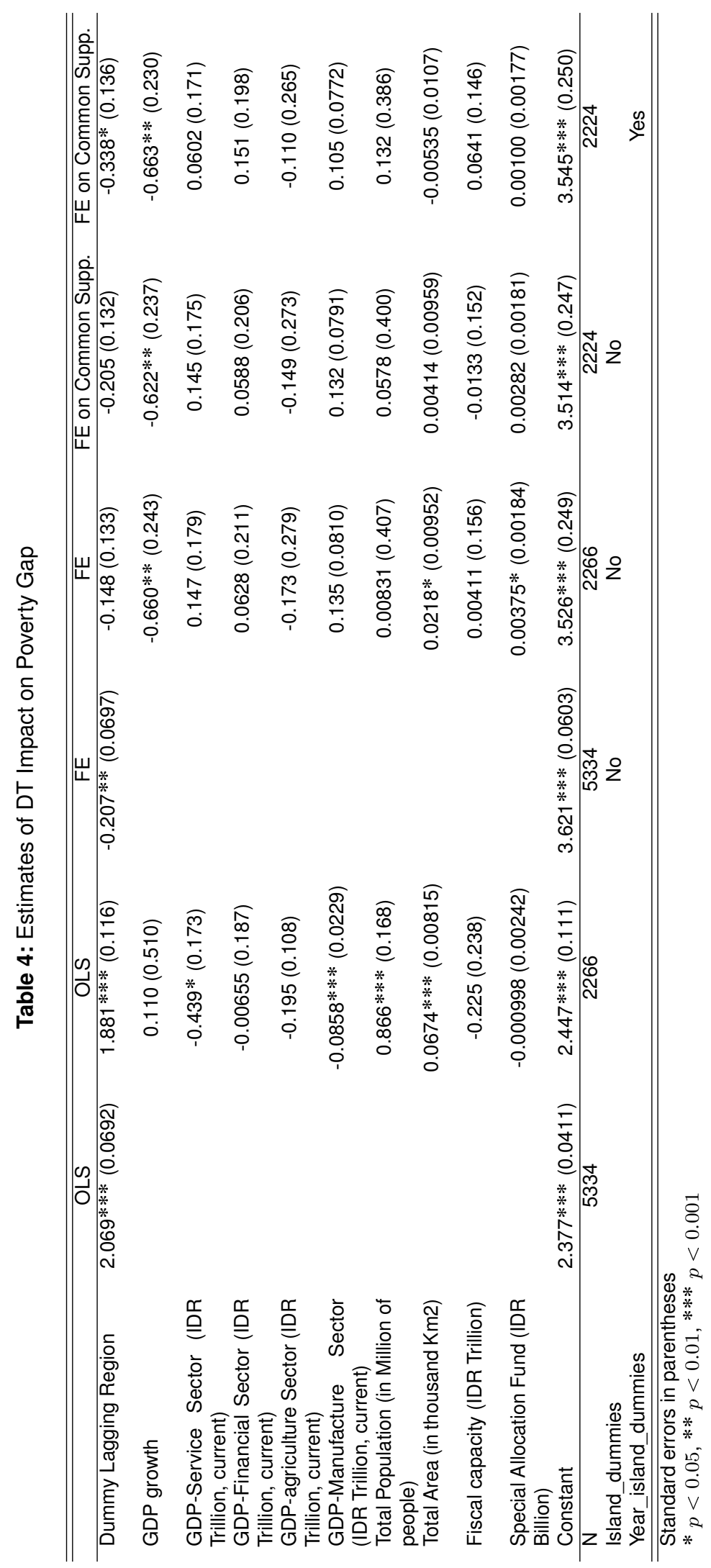

Economics and Finance in Indonesia Vol. 62 No. 1, April 2016, pp. 30-43 
Review of Government's Poverty Reduction Strategies, Policies and Programs in Indonesia, SMERU Research Institute, Jakarta.

[12] Tuwo, LD 2010, The National Medium Term Development Plan (RPJMN) 2010-2014, National Development Planning Agency, Jakarta.

[13] Vidyattama, Y 2013, 'Regional Convergence and the Role of the Neighbourhood Effect in Decentralised Indonesia', Bulletin of Indonesian Economic Studies, vol. 49, no. 2, pp. 193-211.

[14] Voss, J 2008, Impact Evaluation of the Second Phase of the Kecamatan Development Program in Indonesia, The World Bank. 


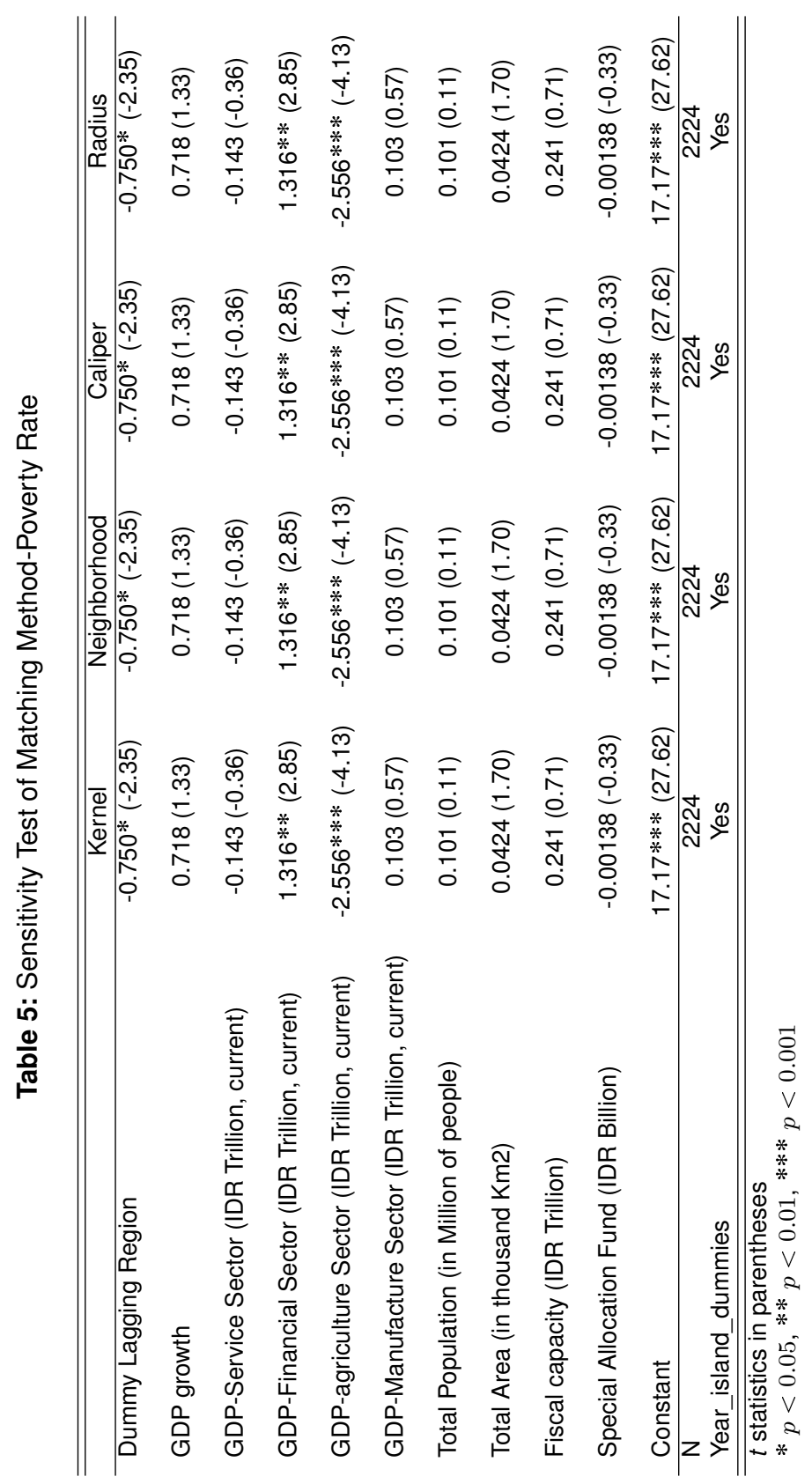




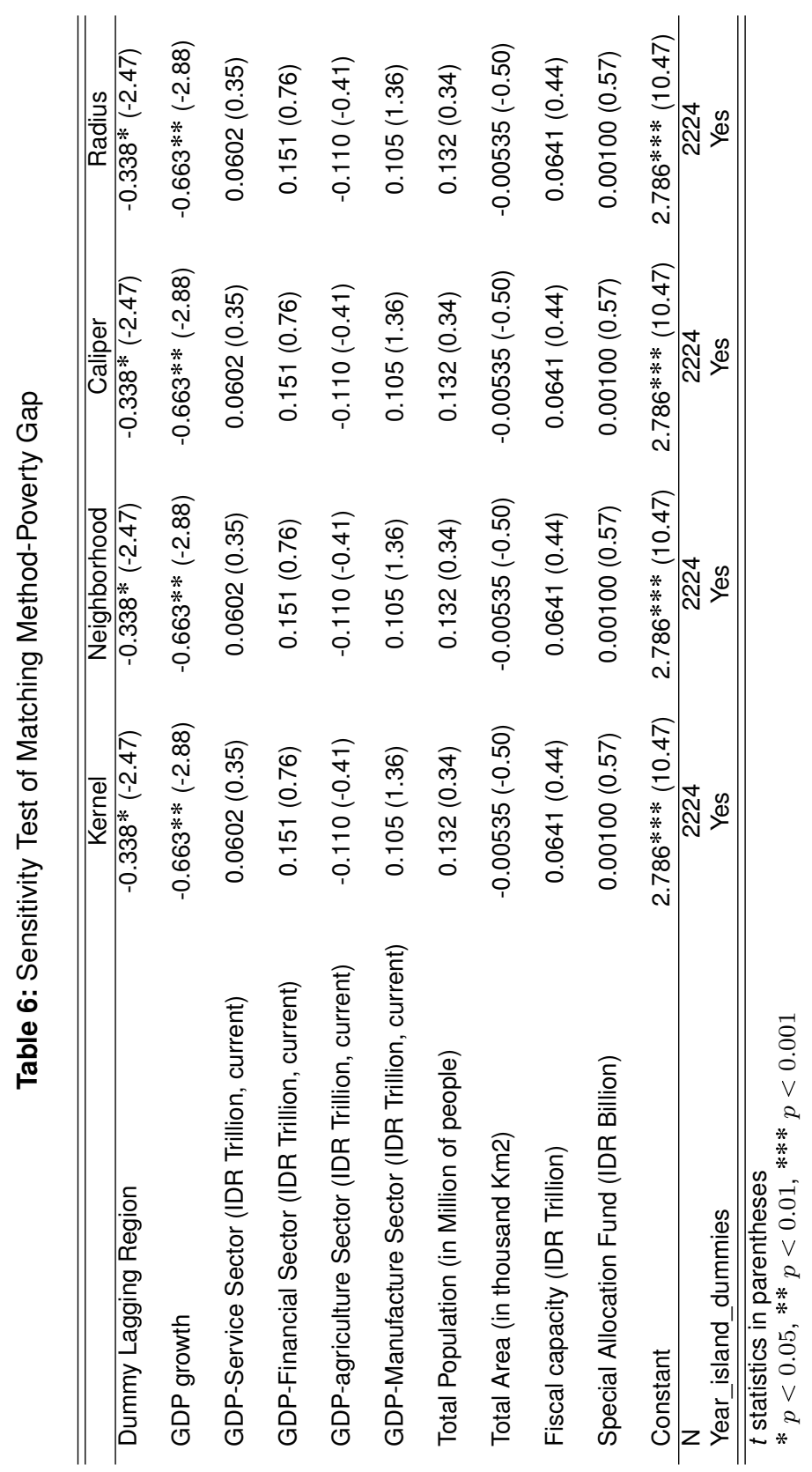

